\title{
A CONCEPTUAL FRAMEWORK FOR THE NEW ZEALAND TORT OF INTRUSION
}

\author{
NA Moreham*
}

This article examines the desirable scope of the New Zealand tort of intrusion into seclusion. It begins by developing a six-part taxonomy of common law privacy interests and then, using that taxonomy as its starting point, asks which privacy interests the New Zealand intrusion tort should cover. It argues that although the intrusion tort is a very welcome addition to New Zealand common law, it is important that its parameters are clearly delineated. The best way to achieve that, it is suggested, is by recognising that unwarranted listening, watching or recording of private activities is the gravamen of the new tort.

\section{INTRODUCTION}

Since the turn of the century, two important privacy torts have entered the New Zealand common law landscape. The first, established by a majority of the Court of Appeal in Hosking $v$ Runting in 2004, protects against highly offensive publicity being given to private facts or information. ${ }^{1}$ The second, first recognised by the High Court in C v Holland in 2012, protects against highly offensive intrusions into intimate personal activity, space or affairs. ${ }^{2}$ Recognition of these actions - which reflect similar developments elsewhere in the Commonwealth - represents a significant step forward in the protection of privacy in New Zealand. Questions remain, however, about the precise scope of the two actions and the relationship between them.

This article examines those questions in respect of the tort of intrusion into seclusion. It does this, first of all, by identifying retreat and inaccessibility as the basis for New Zealand common law

\footnotetext{
* Associate Professor in Law, Victoria University of Wellington. I would like to thank participants at the 2016 New Zealand Private Law Roundtable (at which a draft of this article was presented) and Dr Eric Descheemaeker, Edinburgh University, for helpful and stimulating comments. Thanks also to Callum Beattie for valuable assistance in preparing the final manuscript. The usual disclaimers apply.

$1 \quad$ Hosking $v$ Runting [2005] 1 NZLR 1 (CA).

$2 C$ c Holland [2012] NZHC 2155, [2012] 3 NZLR 672.
} 
understandings of privacy and providing a taxonomy of six sub-interests that fall within that interest. Then, in Part III, the article discusses which of those six privacy sub-categories should come within the scope of the intrusion tort. Finally, in Part IV, the intrusion tort is reformulated so that it is clear precisely what behaviour it seeks to proscribe and on what legal basis.

Before embarking on this exercise, it should be acknowledged that a relative paucity of case law and the absence of Supreme Court endorsement of either of the privacy torts mean that there is still some uncertainty about the status of the New Zealand privacy actions. ${ }^{3}$ This article will not deal with these issues of status expressly; for the purpose of the ensuing discussion, it will be assumed that some version of each tort will continue to be part of our law. It is hoped, however, that by explaining how the intrusion tort can be clearly and coherently developed, the case for allowing the privacy torts to become a fully-fledged part of the common law will be strengthened.

\section{A CONCEPTUAL FRAMEWORK FOR THE NEW ZEALAND COMMON LAW OF PRIVACY}

\section{A Privacy as Retreat or Inaccessibility}

The protection of privacy in New Zealand common law has at its heart the idea of retreat or inaccessibility. It is about the ability to remove oneself from the world, to keep certain information beyond the reach of others and to exclude strangers from our innermost spaces. Privacy therefore protects a realm in which we are entitled to choose, on our own terms, the extent to which we are accessed by others.

This retreat-based conception of privacy has been expressly recognised by New Zealand appellate judges. For example, in the Supreme Court case of Brooker v Police McGrath J said (citing this author) that the privacy interest includes both a right to be free from unwanted physical access and a separate but overlapping category concerned with the "desire to be free from unwanted access to private information". ${ }^{4}$ In Hosking $v$ Runting, Tipping J also explained that: ${ }^{5}$

3 In the only Supreme Court case to consider the matter, McGrath J (with whom Tipping and Blanchard JJ concurred) adopted the parties' approach of assuming that there is a privacy tort and that the limits of the privacy action were as stated by the majority in Hosking. It was therefore "unnecessary" to consider Hosking in detail: Rogers v Television New Zealand Ltd [2007] NZSC 91, [2008] 2 NZLR 277 at [99]. Anderson $\mathrm{J}$ agreed with this approach but said that both the existence and requirements of the privacy tort would need to be reviewed by the Supreme Court in an appropriate case: Rogers at [144]. Elias CJ emphasised the differences between the claims in Hosking and Rogers (particularly the overlap with breach of confidence in the latter) and stressed that the Court of Appeal in Hosking "did not purport to establish the limits of the tort in all circumstances": Rogers at [23]. She therefore disagreed with the majority approach of adopting the Hosking test for the purposes of the Rogers appeal.

4 Brooker v Police [2007] NZSC 30, [2007] 3 NZLR 91 at [123] citing NA Moreham "The Protection of Privacy in English Common Law: a doctrinal and theoretical analysis" (2005) 121 LQR 628 at 640-641. See also Thomas J's description of the home as a "sanctuary" and a place "to retreat or repair to": Brooker at [257]. 
Privacy is potentially a very wide concept; but, for present purposes, it can be described as the right to have people leave you alone if you do not want some aspect of your private life to become public property. Some people seek the limelight; others value being able to shelter from the often intrusive and debilitating stresses of public scrutiny ... It is of the essence of the dignity and personal autonomy and well-being of all human beings that some aspects of their lives should be able to remain private if they so wish. Even people whose work, or the public nature of whose activities make them a form of public property, must be able to protect some aspects of their lives from public scrutiny.

Recognition of this need for retreat and inaccessibility and of the sanctity of the domestic sphere has a long been a feature of the common law. As early as 1765, the plaintiff in Entick $v$ Carrington successfully complained that the King's messengers: ${ }^{6}$

... broke open the doors to the rooms, the locks ... the boxes, chests, drawers, etc ... and read over, pryed into, and examined all [his] private papers, books, etc" as a result of which "the secret affairs, etc of the plaintiff became wrongfully discovered and made public".

And in the 1849 case of Prince Albert v Strange, Vice-Chancellor Knight-Bruce described the unauthorised publication of etchings which Prince Albert had made for his own and his family's private amusement as: ${ }^{7}$

... an intrusion - an unbecoming and unseemly intrusion ... offensive to that inbred sense of propriety natural to every man - if intrusion, indeed, fitly describes a sordid spying into the privacy of domestic life - into the home (a word hitherto sacred among us) ...

Some 152 years later, the need to protect physical and metaphorical space was recognised by Mustill LJ (as he then was) in $R v$ Broadcasting Standards Commission, ex p BBC: ${ }^{8}$

To my mind the privacy of a human being denotes at the same time the personal "space" in which the individual is free to be itself, and also the carapace, or shell, or umbrella, or whatever other metaphor is preferred, which protects that space from intrusion. An infringement of privacy is an affront to the personality, which is damaged both by the violation and by the demonstration that the personal space is not inviolate.

5 Hosking $v$ Runting, above n 1, at [238]-[239] (emphasis added). See also Lake v Wal-mart Stores $582 \mathrm{NW}$ 2d 231 (Minn 1998) at 235 per Blatz CJ: "The right to privacy is an integral part of our humanity; one has a public persona, exposed and active, and a private persona, guarded and preserved. The heart of our liberty is choosing which parts of our lives shall become public and which parts we shall hold close."

6 Entick v Carrington (1765) 2 Wils KB 275 at 275, (1795) 95 ER 807 (KB) at 807.

7 Prince Albert v Strange (1849) 2 De G \& SM 652 at 698, (1849) 64 ER 293 (Ch) at 313.

$8 \quad R v$ Broadcasting Standards Commission, ex parte British Broadcasting Corp [2001] QB 885 (CA) at [48]. The Court of Appeal upheld the Broadcasting Standards Commission's decision that the secret filming of sales assistants inside an electronics store was a breach of privacy. 
The ideas of retreat and inaccessibility which underpin these dicta also feature strongly in academic writing. For example, Samuel Warren and Louis Brandeis explained in their celebrated 1890 article that the intensity and complexity of modern life "have rendered necessary some retreat from the world". ${ }^{9}$ They therefore stressed the importance of "the right of the individual to be let alone", of "inviolate personality" and "a right to privacy". ${ }^{10}$ Other scholars articulate this need for retreat through the concept of access. For example, in Ruth Gavison's widely adopted definition, privacy is seen as "a limitation of others' access to an individual" which is lost whenever a person finds out about, pays attention to, or gets close enough to a person to touch or observe him or her through the normal use of the senses. ${ }^{11}$ Ernest van den Haag also defines privacy as the exclusive access of a person to a realm of his or her own, the right to which entitles a person to exclude others from watching, utilizing, or invading his or her private realm. ${ }^{12}$ More recently, Kirsty Hughes has said that "an invasion of privacy occurs when $\mathrm{Y}$ (the intruder) breaches a privacy barrier used by $\mathrm{X}$ (the privacy-seeker) to prevent $\mathrm{Y}$ from accessing $\mathrm{X} " .{ }^{13}$

\section{B Creating a Taxonomy of Privacy Interests}

The human need for retreat or inaccessibility can, therefore, be seen as the value underpinning the New Zealand torts of breach of privacy. In order to understand the nature of the privacy interest, however, this concept of access needs to be deconstructed further. We need to know what typical breaches of privacy look like, how they can be distinguished from one another and whether they can be usefully categorised. Case law and popular discourse provide a useful launching pad for this kind of discussion. So if you were to ask an average group of New Zealanders what a breach of privacy looks like what might they say?

The first thing a typical group of individuals might talk about when asked what amounts to a breach of privacy is the dissemination of private material in the media, on the internet or elsewhere. They might point to a recent media exposé of a public figure's philandering, for example, to instances of ex-partners posting explicit sexual photographs on social media, or of hackers posting hacked financial records online. They might also tell you it would be a breach of their privacy to

9 Samuel D Warren and Louis D Brandeis "The Right to Privacy" (1890) 4 Harv L Rev 193 at 196.

10 At 205, 211 and 213 respectively.

11 Ruth Gavison "Privacy and the Limits of the Law" (1980) 89 Yale LJ 421 at 428-33.

12 Ernest van den Haag "On Privacy" (1971) 13 NOMOS 149 at 149.

13 Kirsty Hughes "A Behavioural Understanding of Privacy and its Implications for Privacy Law" (2012) 75 MLR 806 at 810. See also Michael Weinstein "The Uses of Privacy in the Good Life" (1971) 13 NOMOS 88 at 94 who defines privacy as a condition of voluntary limitation of communication to or from certain others with respect to specified information of "perceived good"; and Stanley Benn "Privacy, Freedom and Respect for Persons" (1971) 13 NOMOS 1 at 3-4 who says that the right to privacy includes a claim "not to be watched, listened to, or reported upon without leave, and not to have public attention focused upon one uninvited". 
watch them in their bathrooms, to listen in on their telephone conversations, or to video them surreptitiously in their bedrooms. And perhaps they would say that it would be a breach of privacy for you to enter their home or hotel room, to lie in their bed, rifle through their drawers or to go through their wallet, car glove box or smartphone.

All of these activities have been held to be part of a right to privacy by common law courts in New Zealand, and/or other common law jurisdictions. In New Zealand, it is actionable surreptitiously to film someone in the shower, to publish intimate sexual images without the subject's consent, or to reveal private information about, for example, a person's struggles with mental illness, the fact that he or she has made a sex offence complaint, or that he is a boy whose mother was allegedly murdered by his father. ${ }^{14}$ In England, Canada, Australia and the United States, defendants have been liable for kissing-and-telling, publishing naked photographs or videos, for revealing health information or the contents of someone's diary, listening in on people's conversations, spying on or videoing people engaged in private acts, or entering a person's home without leave. ${ }^{15}$

Multifarious though they are, these different types of privacy interference can be organised into two main categories: the misuse of private information (informational privacy) and unwanted physical access (physical privacy). ${ }^{16}$ The principal objection in the first category - the informational

14 See respectively $C v$ Holland, above n 2; $L v G$ [2002] NZAR 495 (DC); $P v D$ [2000] 2 NZLR 591 (HC); $A$ v Fairfax New Zealand Ltd HC Wellington CIV-2011-485-569, 28 March 2011; JJC v Fairfax New Zealand Ltd HC Auckland CIV-2011-404-5605, 15 September 2011. See also Brown v Attorney-General [2006] NZAR 552 (DC) in which police were found liable for distributing a flier identifying the plaintiff (by full name and photograph) as a convicted paedophile living in the area.

15 See for example PJS v News Group Newspapers Ltd [2016] UKSC 26, [2016] 2 WLR 1253 (regarding kissing-and-telling and sexual information); AMP v Persons Unknown [2011] EWHC 3454 (TCC), Jane Doe 464533 v ND 2016 ONSC 54, 2016 CarswellOnt 911, Wilson v Ferguson [2015] WASC 15 (all regarding sexual images); Campbell v MGN Ltd [2004] UKHL 22, [2004] 2 AC 457 (regarding health information); Associated Newspapers Ltd v HRH Prince of Wales [2006] EWCA Civ 1776, [2008] Ch 57 (regarding the diary); Roach v Harper 105 SE 2d 564 (WVa 1958) (regarding intercepted calls); Malcolm v Fleming 2000 CarswellBC 1316 (BCSC), Lee v Jacobson 1992 CarswellBC 1119 (BCSC) (both regarding spying on a videoing private acts); and Miller v National Broadcasting Co 187 CalApp 3d 1463 (Cal App 2 Dist 1986) (regarding entering a person's home).

16 For a fuller development of this argument see NA Moreham "Beyond Information: Physical Privacy in English Law" (2014) 73 CLJ 350; and Moreham, above n 4. Many academics divide the concept along similar lines: see for example Gavison, above n 11, at 428-440; Daniel J Solove "A Taxonomy of Privacy" (2006) 154 U Pa L Rev 447 at 489; Tom Gerety "Redefining Privacy" (1977) 12 Harv CR-CL Law Rev 233 at 261ff; Benn, above n 13; James Rachels "Why Privacy is Important" (1975) 4 Philosophy and Public Affairs 323 at 326; Judith Wagner De Cew "The Scope of Privacy in Law and Ethics" (1986) 5 L \& Phil 145 at 153-158; van den Haag, above n 12, at 149-153; Rachael Mulheron "A Potential Framework for Privacy? A Reply to Hello!" (2006) 69 MLR 679 at 696-701; Chris Hunt "Conceptualizing Privacy and Elucidating its Importance: Foundational Considerations for the Development of Canada's Fledgling Privacy Tort" (2011) 37 Queen's LJ 167 at 201; Raymond Wacks Privacy and Media Freedom (Oxford University Press, Oxford, 2013) at ch 6; and Hughes, above n 13, at 810-811. See also Australian Law Reform 
privacy cases - is to the fact that someone is finding out something about you against your wishes. Perhaps he or she learns that you have a sexually-transmitted disease, that you enjoy cross-dressing in private, or that you are having relationship difficulties. These informational privacy interferences, in turn, take two main forms. First, a person can discover things about you that you wish to keep to yourself (by reading your diary, acquiring your bank records, hacking your e-mails, for instance). And, secondly, the person can disclose private information about you to others, by passing on gossip, uploading private material to the internet, or disseminating it in the media, for example.

The second category - physical privacy - is about unwanted access to the physical self. The interference in these cases is primarily sensory and spatial: the intruder interferes with your physical privacy by watching or listening to you against your wishes, by recording you, or by getting access to your personal spaces. It is these physical aspects of the interest which are at stake when a person spies on you in the shower, hacks your telephone calls, videos you in your bedroom or breaks into your home when you are not there. As with informational privacy, there is more than one way to interfere with physical privacy. First, physical privacy is interfered with if a person observes you against your wishes (including with technological aids), for instance, by spying on you as you get changed, filming you in the bathroom, bugging you during an intimate telephone call, or entering your home while you are not there. Secondly, it is compromised when a person photographs or otherwise records these private activities for their own or others' future reference. Thirdly, it is a breach of physical privacy to enable others to see or hear you engaged in private activities by disseminating photographs or recordings of those private activities to others. Finally, a person can breach your privacy simply by obtaining physical proximity to you or your intimate spaces or belongings; for example, by entering your house, lying in your bed, or going through your backpack, wallet or cupboards without your consent. ${ }^{17}$ In all of these situations, the concern is primarily physical: the observer is, through the use of the senses or physical proximity, physically experiencing something of you against your wishes and/or allowing others to do the same. ${ }^{18}$

Commission Serious Invasions of Privacy in the Digital Era: Final Report (ALRC R123, 2014) at ch 5. For discussion of physical privacy see Richard Parker "A Definition of Privacy" (1974) 27 Rutgers L Rev 275 at $275-288$.

17 This is the case even if the person does not see, hear or find out about anything private (if for example he or she broke into your home and simply sat in your bedroom in the dark). Researchers have demonstrated in a forthcoming study that the mere presence of another person can affect a subject's willingness to make personal disclosures in an on-screen survey even if the third party is unable see the subject or what he or she is writing: see Alessandro Acquisti, Laura Brandimarte and Jeff Hancock "Online Self-Disclosure and Offline Threat Detection" (paper presented to the 14th Annual Workshop on the Economics of Information Security, Delft, June 2015).

18 There is, of course, overlap between the physical and informational categories. A person who hacks your telephone will not only hear you talking but in all likelihood discover sensitive personal information as well. But the concepts remain analytically distinct and, even in cases of overlap, help ensure that all the consequences of a breach of privacy are properly recognised and compensated. 


\section{WHAT SHOULD THE NEW ZEALAND INTRUSION TORT PROTECT?}

So what does all this tell us about the desirable development of privacy protection in New Zealand common law? Or more particularly - to return to this article's central inquiry - what role should the new intrusion tort play in protecting physical and informational privacy and the six subcategories which fall within them?

\section{A What is Already Covered by the Publicity Tort}

The answer to this question about the desirable role of the intrusion tort depends in large part on the privacy-protection role already played by the tort of giving publicity to private facts. This tort was first recognised by the Court of Appeal in New Zealand's leading privacy case, Hosking $v$ Runting. ${ }^{19}$ In that decision, a television presenter and his former wife sought to restrain publication of photographs of their 18-month old twins being wheeled down a busy Auckland shopping street in a push chair. ${ }^{20}$ The plaintiffs claimed that the photographs breached the children's privacy and, given the celebrity status of the first plaintiff, potentially jeopardised their safety. All five judges agreed that there was no breach of privacy in the circumstances (because the photographs were of an innocuous event which took place in public) but three of the five nonetheless held that there was a tort of breach of privacy in New Zealand.

Two of the majority judges, Gault $\mathrm{P}$ and Blanchard $\mathrm{J}$, held that the tort has two requirements: first, the existence of facts in respect of which there is a reasonable expectation of privacy and second, publicity given to those private facts that would be considered highly offensive to an objective reasonable person. ${ }^{21} \mathrm{~A}$ defence of legitimate public concern was also recognised. ${ }^{22}$ Tipping $\mathbf{J}$, the third member of the majority, defined the tort more broadly. He asked whether the plaintiff had a reasonable expectation of privacy in respect of private "information or material" (not just facts) and argued persuasively that the highly offensive test was unnecessary (and said that even if it were retained, a requirement of substantial offence would be enough). ${ }^{23}$

19 Hosking $v$ Runting, above $\mathrm{n} 1$.

20 They brought the action on behalf of their children.

21 Hosking $v$ Runting, above $\mathrm{n} \mathrm{1,} \mathrm{at} \mathrm{[117].} \mathrm{Explaining} \mathrm{the} \mathrm{highly} \mathrm{offensive} \mathrm{test} \mathrm{further} \mathrm{they} \mathrm{said} \mathrm{at} \mathrm{[128]:} \mathrm{"The}$ concern is with publicity that is truly humiliating and distressful ... The right of action, therefore, should be only in respect of publicity determined objectively, by reference to its extent and nature, to be offensive by causing real hurt and harm".

22 At [129].

23 At [249] and [256] respectively. Tipping $\mathbf{J}$ is not the only appellate judge to doubt the desirability of the highly offensive test. In Rogers $v$ Television New Zealand Ltd, above n 3, at [25] Elias CJ (with whom Anderson J concurred) held that the Supreme Court should "reserve its position on the view ... that the tort of privacy requires not only a reasonable expectation of privacy but also that publicity would be 'highly offensive'". The desirability of the high offensiveness test is also doubted in Rogers $v$ TVNZ Ltd [2007] 1 
All three majority judges restricted the tort to situations where publicity has been given to the private material in question. Thus, although the action would potentially cover cases where the media published intimate details of a public figure's health problems or extra-marital affair, it does not extend to the mere acquisition of that information (if, for example, a defendant accessed but did not publish the public figure's medical or telephone records). Nor does it extend to situations where a defendant merely watches, records or physically encroaches on a claimant; Gault P and Blanchard $\mathrm{J}$ left open the question of whether a tort of unreasonable intrusion into solitude and seclusion should be developed at some future time. ${ }^{24}$ Liability for limited disclosures was also excluded, at least by Gault P and Blanchard J. A disclosure will not be highly offensive, they said, unless it involves "widespread publicity of very personal and private matters": "publication" in the "technical sense" that it applies in defamation - that is, to one or a small number of persons - was said not to be "in issue". ${ }^{25}$ So, on this approach, there could be no recovery for breach of privacy if an exboyfriend sent naked photographs of a woman to a handful of her work colleagues or a medical centre employee told a woman's religious elders that she had had an abortion. ${ }^{26}$

As mentioned, the Supreme Court has declined so far to consider whether the Hosking majority's formulation of the privacy tort should be applied in future cases. ${ }^{27}$ As it stands though, the publicity tort covers just two of the six sub-categories of privacy interest identified above: the dissemination of private information (part of informational privacy) and of photographs, videos and other recordings (part of physical privacy). Four of the six subcategories in the taxonomy therefore fall outside it. The next question is what role the intrusion tort should play in protecting those remaining interests.

NZLR 156 (CA) at [122] per William Young P; NA Moreham "Why is Privacy Important? Privacy, Dignity and the Development of the New Zealand Breach of Privacy Tort" in Jeremy Finn and Stephen Todd (eds) Law, Liberty and Legislation (LexisNexis, Wellington, 2008) at 231; Thomas Levy McKenzie "The New Intrusion Tort: The News Media Exposed?" (2014) 45 VUWLR 79 at 95-97; and Chris DL Hunt "New Zealand's New Privacy Tort in Comparative Perspective" (2013) 13 OUCLJ 157 at 163-165.

24 Hosking v Runting, above $\mathrm{n}$ 1, at [118]. As will be discussed below, such an action has now been developed.

25 At [125]. Tipping J does not deal with the matter expressly.

26 These situations might, however, fall within breach of confidence; in both the examples just given, the material is likely to have been acquired in the context of a relationship of confidence. In Giller v Procopets [2008] VSCA 236, (2008) 24 VR 1 for example an estranged husband was liable in breach of confidence for showing a sex tape of the plaintiff to the mother of one of her friends. See further Ursula Cheer Burrows and Cheer: Media Law in New Zealand (7th ed, Lexis Nexis, Wellington, 2015) at ch 5 for a general discussion of breach of confidence; JF Burrows in Stephen Todd (ed) The Law of Torts in New Zealand (6th ed, Thompson Reuters, Wellington, 2013) at [17.5.05(1)] on the relationship between privacy and breach of confidence; and the discussion of breach of confidence below at 299-301.

27 See above $\mathrm{n} 3$ and below $\mathrm{n} 34$. 


\section{B How Far Should the Tort of Intrusion Into Seclusion Extend?}

The tort of intrusion into solitude or seclusion was first recognised by Whata $\mathrm{J}$ in the 2012 case of $C v$ Holland. ${ }^{28}$ The plaintiff in that case sued her flatmate for damages after he videoed her through a hole in the ceiling while she was having a shower. Proceedings were brought to establish the preliminary issue of "whether invasion of privacy of this type, without publicity or the prospect of publicity, is an actionable tort in New Zealand". ${ }^{29}$ Whata $\mathrm{J}$ held that it was, regarding the tort of intrusion into seclusion as "entirely compatible with, and a logical adjunct to, the Hosking tort of wrongful publication of private facts". ${ }^{30}$ Both torts were said to "logically attack the same underlying wrong, namely unwanted intrusion into a reasonable expectation of privacy". 31

According to Whata $J$, the New Zealand intrusion tort has four key requirements: ${ }^{32}$

(a) An intentional and unauthorised intrusion;

(b) Into seclusion (namely intimate personal activity, space or affairs);

(c) Involving an infringement of a reasonable expectation of privacy;

(d) That is highly offensive to a reasonable person

A legitimate public concern in the information may provide a defence. ${ }^{33}$ The last two elements, Whata $\mathbf{J}$ observed, are also part of the tort of giving wrongful publication to private facts (at least as articulated by Gault $\mathrm{P}$ and Blanchard $\mathrm{J}$ in Hosking) and the boundaries of that tort will therefore inform development of the intrusion tort where relevant. ${ }^{34}$ But the action's principal influence is the United States tort of unreasonable intrusion into seclusion which, according to the Restatement of Torts (Second), imposes liability if a person intrudes physically or otherwise, upon the seclusion of another or his or her private affairs or concerns if the intrusion would be highly offensive to a reasonable person. ${ }^{35}$

28 C v Holland, above $\mathrm{n} 2$.

29 At [1]. The case settled before the substantive hearing took place.

30 At [75].

31 At [75].

32 At [94]. For a useful discussion of each of these requirements, see McKenzie, above n 23.

$33 C v$ Holland, above n 2, at [96]. But as will be explained, this focus on "information" is probably inappropriate: see below at 301 .

34 At [96].

35 American Law Institute Restatement of Torts (2nd ed, Philadelphia, 1977) §652B as discussed in $C v$ Holland, above n 2, at [11]-[20]. United States law also informed the development of the publicity tort: see Hosking above n 1, at [117]. 
The existence of the tort in New Zealand has been implicitly accepted in a handful of cases since Holland, including by the Court of Appeal. ${ }^{36}$ This is welcome. These developments rightly recognise that breaches of privacy do not always involve the disclosure, nor even the acquisition, of private information. Instead, the objection in many cases is to the act of observing, recording or physically encroaching on a person per se. The intrusion tort therefore recognises that, although it is a serious breach of privacy secretly to spy on a person in the shower, to film a child changing at a swimming pool, or to record a father playing with his children in their bedroom, this is not because of the information obtained by the intruder. Instead, the objection is to the fact that the voyeur is looking at the claimant when he or she does not wish to be observed; that the watcher has insinuated him or herself in at a private moment. As Raymond Wacks says: ${ }^{37}$

What is essentially in issue in cases of intrusion is the frustration of the legitimate expectations of the individual that he should not be seen or heard in circumstances where he has not consented to or is unaware of such surveillance. The quality of the information thereby obtained, though it will often be of an intimate nature, is not the major objection.

\section{The need for a conceptual anchor}

Although recognition of the intrusion tort is a positive step, questions remain about its desirable scope. Unlike the narrowly-drawn Hosking test, Whata J's formulation of the intrusion action is very broad. Indeed, if the words of Whata J's test are taken at face value (without consideration for the underlying values the judge was seeking to protect) the action would extend well beyond the intrusion at issue in Holland. Judges in the United States have, for example, used the intrusion tort to provide protection against sexual harassment in the workplace. ${ }^{38}$ Even if New Zealand judges do not go this far, there is significant scope for the intrusion tort to tread on the toes of existing legal actions. For example, widespread publication of private information could readily be seen as a highly offensive intrusion into "intimate personal activity, space or affairs" thus undermining the narrow boundaries of the Hosking tort. Stalking and unauthorised entry on to private property currently the preserve of the Harassment Act 1997 and trespass, respectively - could also fall within the scope of Whata J's formulation. ${ }^{39}$

36 Graham v R [2015] NZCA 568 at [22]ff; Faesenkleot v Jenkin [2014] NZHC 1637 at [35]ff (but compare at [38] where Asher $\mathbf{J}$ doubted whether there is a need for separate torts for publication of private facts and intrusion); Henderson v Slevin [2015] NZHC 366 at [62]ff; and Duval v Clift [2014] NZHC 1950 at [84].

37 Raymond Wacks Personal Information: Privacy and the Law (Clarendon Press, Oxford, 1989) at 248.

38 See for example Phillips v Smalley Maintenance Services Inc 435 So 2d 705 (Ala 1983) at 711; Sphere Drake Insurance Plc v Shoney's Inc 923 F Supp 1481 (MD Ala 1996) at 1490; Kelley v Worley 29 F Supp 2d 1304 (MD Ala 1998) at 1311; and Scott v Estes 60 F Supp 2d 1260 (MD Ala 1999) at 1275.

39 See for example Galella v Onassis 353 F Supp 196 (SDNY 1972) at 228; and Miller v National Broadcasting Co, above n 15, respectively. 
On one view, this breadth in the intrusion tort's formulation is desirable. Why not, it could be asked, let the intrusion action expand to fill the space left by the Hosking tort? Could courts not just use the highly offensive test to keep the action within bounds on a case-by-case basis? The reason why not is that too broad a conception of the intrusion tort would rob the action of its moral force as with any new legal development it needs to be clear what mischief the new tort is aimed at and why. Formulating the intrusion tort too broadly would also lead to unacceptable uncertainty. The subjective nature of the interest at the heart of interferences with privacy - a desire for retreat or inaccessibility - means that privacy actions need to retain a degree of subjectivity and flexibility. But this does not mean that they need to be unclear or imprecise. In fact, it is important that they are not. Uncertainty about what people can and cannot do creates fertile ground for vexatious or unmeritorious litigation. The threat of such litigation is often enough to silence a person who is legitimately asking difficult questions or to bully a person with whom one is in conflict. And although a requirement that the intrusion be "highly offensive to a reasonable person" might help courts dispose of unmeritorious claims once they get to court, this is a capricious concept which cannot be readily understood in advance. ${ }^{40}$ Much better to develop an intrusion action with a clear conceptual anchor, targeting precisely-delineated behaviour and applying readily-identifiable criteria for determining the existence of a reasonable expectation of privacy.

40 Unlike the reasonable expectation of privacy test (see for example Murray $v$ Express Newspapers Plc [2008] EWCA Civ 446, [2009] Ch 481 at [36]), judges' conclusions on the offensiveness of a publication or intrusion often contain little reasoning that can be applied in future cases. For example Gault P's and Blanchard J's conclusion on the offensiveness of the proposed publication in Hosking $v$ Runting, above $\mathrm{n} 1$, at [165] was simply "We can't see any real harm in it"; in Henderson v Slevin, above n 36, at [48] and [71] Associate Judge Osborne said, without explaining why, that a reasonable person would not think it highly offensive for a liquidator to pass on the plaintiff's computer records to an enforcement unit nor to examine them himself; and in Clague v APN Ltd [2012] NZHC 2898 at [38] Toogood J said without giving reasons that, in spite of the fact that they would undoubtedly be embarrassing to the plaintiff and distressing to him and his family, he was not persuaded that publicity around police investigation into allegations of domestic assault would be highly offensive or objectionable to a reasonable person. Some limited guidance on the requirements of the action can be found in Faesenkleot v Jenkin, above n 36, at [46]-[50] where Asher J says that the fact that the filming was incidental to another purpose and there was a weak reasonable expectation of privacy made it less offensive. In Andrews v TVNZ HC Auckland CIV 2004-404-3536, 15 December 2006 at [67]-[73] Allan J also said that the broadcast of the plaintiffs being extricated from a car wreck was not offensive because it did not show the plaintiffs in a "bad light" or otherwise embarrass them and because the plaintiffs expressed their concern as "chagrin and annoyance" rather than humiliation or distress but this approach has been widely criticised: see Moreham, above n 23, at 240-243; Lisa Tat "Plaintiff Culpability and the New Zealand Tort of Invasion of Privacy" (2008) 39 VUWLR 365 at 379 380; Chris Hunt "Breach of Privacy as a Tort" [2014] NZLJ 286; and Jennifer Moore "Traumatized Bodies: Towards Corporeality in New Zealand's Privacy Tort Law Involving Accident Survivors" (2011) 24 NZULR 387 at 402-405. See also Ursula Cheer "The Future of Privacy: Recent Legal Developments in New Zealand" (2007) 13 Canta LR 169 at 183-185 for related criticism of the judge's application of the public interest defence. 
What then is the New Zealand intrusion tort's conceptual anchor? A closer look at the New Zealand judgments confirms that the intrusion tort was not intended to be a general catch-all privacy action. Whata $\mathrm{J}$ makes it clear throughout Holland that the tort is about physical imposition on personal privacy - spying, observation, surveillance, prying, barging in. Phrases like "intrusion into personal space and affairs" and "surveillance and intrusion" therefore appear throughout the judgment. ${ }^{41}$ And when considering the extent to which the interest has been recognised by New Zealand legislators, Whata $\mathrm{J}$ describes the intrusion interest as: ${ }^{42}$

... freedom from unauthorised and unreasonable physical intrusion or prying into private or personal

places such as the home, and freedom from unauthorised recordings of personal, particularly intimate

affairs whether published or not.

Consistently with that, Whata $\mathrm{J}$ identifies legislation which protects against surveillance, intimate visual recordings, and entering private property as relevant to our understanding of the action. ${ }^{43}$ And, of course, the intrusion at the heart of Holland itself was physical - the defendant looked at and recorded the plaintiff's naked body when she was in a secluded place. It is therefore not surprising that Fogarty J, speaking for the Court of Appeal in Graham v R, said that "[s]eclusion as a concept ... connotes an invasion of physical privacy, impinging on one's personal autonomy". ${ }^{44}$

It follows that the two New Zealand torts align loosely with the two main privacy interests identified in the taxonomy above: the Hosking tort is principally about the protection of private information and the intrusion tort is about physical privacy interests. But this only takes one so far. It will be recalled that informational privacy has two components - the acquisition and dissemination of private information - only the latter of which is covered by the Hosking tort. Physical privacy has four components: observing a person, recording a person, disseminating an intimate recording (which is the only element to fall within Hosking) and obtaining unwarranted physical proximity to a person or his or her intimate things or spaces. The next question then is which of these remaining informational and physical privacy interests the New Zealand intrusion tort should protect and how.

$41 C v$ Holland, above n 2, at [87], [89] and [92].

42 At [32] (emphasis added).

43 At [28]-[31]. The focus on unwanted watching is also reflected in his identification of advances in "prying technology" as a factor making recognition of the tort necessary (at [86]) and his discussion of New Zealand courts' treatment of surveillance in the search and seizure context when considering how the intrusion interest is protected in other areas of law (at [45]-[48]).

44 Graham v R, above n 36, at [26(c)]. 


\section{Unwarranted observation and recording}

It is clear from Holland that the intrusion into seclusion tort protects against unwarranted watching, listening or recording of a person. This is highly desirable. As the facts of Holland and numerous criminal and overseas cases attest, unwarranted spying, eavesdropping and recording is a genuine mischief. There dozens of examples in New Zealand, English, Canadian, United States jurisprudence of landlords who video, spy or eavesdrop on their tenants, ${ }^{45}$ employees or businessowners who spy on people using bathroom facilities or changing rooms at their place of work, ${ }^{46}$ neighbours who video or telephone tap the people next door, ${ }^{47}$ journalists who hack public figures' voicemails ${ }^{48}$ voyeurs who film or peep inside public toilet facilities, ${ }^{49}$ and people who film their family members or visitors to their own homes. ${ }^{50}$ These intrusions cause real harm. Plaintiffs tell of sleeplessness, anxiety, difficulty socialising and working, suspicion of others, feelings of violation and exacerbation of existing mental illness. ${ }^{51}$ And unlike other aspects of the intrusion interest,

45 See for example Malcolm v Fleming, above n 15, where a video camera was installed to record tenant in her bathroom and bedroom; Lee v Jacobson above n 15, where plaintiffs were observed through a peep hole and two-way mirror in their bedroom; and Roach v Harper, above $\mathrm{n} 15$, where a bugging device was installed in a tenant's apartment.

46 See for example Harkey $v$ Abate $346 \mathrm{NW} 2 \mathrm{~d} 74$ (Mich Ct App 1983) and Benitez $v$ KFC National Management 714 NE 2d 1002 (Ill App 2 Dist 1999) where employees spied on women's toilets through ceiling panels at a rollerskating rink and fast food restaurant respectively; Vigon $v$ DPP [1997] EWHC Admin 947, [1998] Crim LR 289 where a man installed a video camera in the changing cubicle of his market stall to film people trying on swimwear; $R v$ Turner [2006] EWCA Crim 63, [2006] 2 Cr App R (S) 51 where a sports centre manager filmed female customers in the shower; and $R v$ Sultan Al-Sayed [2009] EWCA Crim 1922, [2010] 1 Cr App R (S) 86 where a man used a mirror to look at child in leisure centre changing room.

47 See for example $R v$ Sippings [2008] EWCA Crim 46, [2008] 2 Cr App R (S) 58 where a man videoed his teenaged neighbour going about everyday activities in her bedroom over a five year period; and Rhodes $v$ Graham 37 SW 2d 46 (Ky Ct App 1931) and Watts v Klaemt 2007 BCSC 662, 2007 CarswellBC 1000 where the defendants recorded their neighbours' telephone conversations for a year.

48 See for example Gulati v MGN Ltd [2015] EWHC 1482, [2016] FSR 12 (Ch) concerning tabloid hacking of public figures' voicemails.

49 See for example $R v$ Hancock [2010] EWCA Crim 390 where a man filmed women using toilets at the Glastonbury music festival; and $R v$ Ching Choi (EWCA) 7 May 1999 where a man filmed women using the female lavatories in a Chinese supermarket.

50 See for example LAM v JELI 2008 BCSC 1147, 2008 CarswellBC 1784 where a man filmed his former partner and her young daughter in the bathroom of his home; $R$ v IP [2004] EWCA Crim 2646, [2005] 1 Cr App R (S) 102 where a man videoed his adult step-daughter in the shower; and $R v$ Hancock, above n 49 where a man filmed a woman using the toilet in his home.

51 Six of the eight plaintiffs in Gulati v MGN Ltd, above n 48, felt "violated" and/or "sickened" by systematic tabloid hacking of their telephone messages: see [247], [273], [407], [513], [571] and [661]. The surveillance also exacerbated one plaintiff's obsessive paranoid mental health condition (at [569]); another became so distrustful that he still lived in a house surrounded by CCTV cameras years later (at [362]). The plaintiff in $C v$ Holland, above n 2, suffered distress and anxiety so acute that she was unable to go out in 
without the intrusion tort there is no effective common law redress for this kind of voyeurism. ${ }^{52}$ The first two subcategories of the physical privacy interest - unwarranted observation and recording therefore clearly should fall within the intrusion tort.

\section{Disseminating a recording of person engaged in an intimate act}

The third category from the list of physical privacy interferences listed above - disseminating a recording of a person engaged in private activities - is not mentioned expressly in Holland. It fits more readily within the current formulation of the Hosking tort. But the harm at issue in this subcategory - being observed in an intimate image or recording - is often the same as that in question in the Holland case. It is about the fact that someone is seeing or hearing you when you did not want to be observed; that he or she sees a video of you in the shower or hears a recording of you doing or saying something intimate. Recognition of the physical element in these cases is important. To focus just on the information contained in these recordings - about what you do in the shower or toilet, what you say on the telephone or in bed - is to miss the real nature of the objection. And courts do sometimes fall into this trap. When deciding whether there was a reasonable expectation of privacy in respect of the images in Hosking, for example, Gault $\mathrm{P}$ and Blanchard $\mathrm{J}$ focused on the facts which the photographs disclosed about the children - their existence, their ages and the fact that their parents were separated. Since these were already matters of public record, there was held to be no reasonable expectation of privacy in respect of the images. ${ }^{53}$ But, with respect, this was to ask the wrong question; the plaintiffs' real complaint was that, if published, the images would have allowed thousands readers to see the twins on a family outing which would not normally have attracted any outside attention. ${ }^{54}$ The Court needed to address this objection directly rather than reduce the photographs to a series of facts about the children.

public for a week after discovering that her flatmate had filmed her in the shower. Other effects such as insomnia, nightmares, mistrust of others, fear of the defendant, and feelings of shame continued for months after the discovery of the filming: Interview with C (NA Moreham and Yvette Tinsley, Wellington, 27 March 2014)

52 Although it is the subject of criminal sanction: see for example Crimes Act 1961, ss 216B and 216C regarding the prohibition of the use of interception devices and the disclosure of any communications intercepted; Crimes Act 1961, ss 216H, 216I and 216J regarding prohibitions of, respectively, making, possessing, or publishing intimate visual recordings; and Summary Offences Act 1981, s 30 regarding the offence of peeping or peering into a dwelling house at night.

53 Hosking $v$ Runting, above $\mathrm{n}$ 1, at [164]. Tipping J's approach of asking whether there is a reasonable expectation of privacy in respect of the "information or material" which has been published helps avoid this kind of reasoning since it encourages courts to think about the impact of the image as a whole rather just than the facts which it communicates: at [249].

54 Recognising this, English courts have taken a different approach to these sorts of cases: see Murray $v$ Express Newspapers Plc, above n 40; and Weller v Associated Newspapers Ltd [2015] EWCA Civ 1176, [2016] 1 WLR 1541. 
One way to ensure that courts appropriately recognise the physical impacts of images or recordings is to make their publication actionable under both the publicity and intrusion torts (the latter on the basis that it allows others to see plaintiffs' intimate activities for themselves). Courts would then be compelled to consider the physical effects of a publication as part of an intrusion claim. Alternatively - and probably preferably - courts could continue to deal with all issues of dissemination or publicity under the Hosking tort but to recognise expressly that the plaintiff's objection to being seen and/or heard by those who access the material is an important part of the publicity claim. Liability and remedies for the loss of physical privacy should be imposed accordingly.

Whichever approach is taken, it would be inappropriate to apply Gault P and Blanchard J's proposed rule that liability can only attach if the publicity is widespread in cases involving images or recordings. ${ }^{55}$ As courts in other jurisdictions have recognised, disclosure of an intimate image or recording - to one's family, say, or a small group of work colleagues or acquaintances - can be deeply humiliating and distressing to the subject. ${ }^{56}$ The privacy torts should therefore have sufficient flexibility to extend to such conduct where necessary.

\section{Physical incursions on private space}

That leaves just one more subcategory from the taxonomy of physical privacy interests above physical incursions on intimate space. This subcategory was addressed in Holland; Whata J clearly thought that the intrusion tort should extend to "unreasonable physical intrusion ... into private or personal places such as the home..." 57 He does not expressly say what kinds of situations would amount to physical intrusions of this nature but he seems to have in mind the kinds of incursions listed under the sixth subcategory above, including encroachment on private property and perhaps also interference with personal belongings. ${ }^{58}$

Although the right to be free from these kinds of intrusions is an important part of the privacy interest, the case for extending the New Zealand intrusion tort to include it is not entirely clear. The law of trespass already provides protection against unwelcome incursions into bodily integrity, private space and belongings. ${ }^{59}$ Such incursions are actionable without proof of loss and are subject

55 See the discussion above at 290.

56 See for example Giller v Procopets, above, n 26, in which the defendant was liable in breach of confidence for trying to show a sex tape of his former wife to her friends and family. In the privacy context, the extent of the disclosure should be relevant to the assessment of the plaintiff's reasonable expectation of privacy, its offensiveness and to any remedy awarded.

57 C v Holland, above n 2, at [32].

58 Whata J's reference to restrictions on landlords' right of access to tenanted properties as a legislative measure which protects physical privacy supports this interpretation: at [31].

59 See Burrows and Todd, above n 26, at chs 4 (trespass to the person), 9 (trespass to land) and 12.2 (trespass to goods). 
to aggravated damages if the trespass is "accompanied by infliction of injury on the claimant's proper pride and dignity" (which might well include a breach of privacy). ${ }^{60}$ Trespass to land or goods can therefore provide redress if someone enters or remains on your property without consent, rifles through your backpack, goes through your belongings in a hotel or hospital room, breaks into your car, or gains access to your home on false pretences (perhaps as part of a "ride along" with medical officers or emergency personnel, for example). ${ }^{61}$ It is questionable whether we need the intrusion tort to provide additional protection against such activity. Harassment legislation and the offence of being found on property without reasonable excuse provide additional protection against incursions into space including, significantly, in situations where trespass cannot apply because the plaintiff has no proprietary interest in the land in question. ${ }^{62}$ And of course, a defendant who sees, hears or records anything private in the space into which they have intruded (which would include almost anything taking place in a home, hotel room or hospital ward) will already be liable under the intrusion tort for the observation itself.

On the other side of the equation, including physical intrusions into private or personal places would introduce significant uncertainty to the action. Would it be an intrusion into personal places, for example, to go into your flatmate's bedroom when she was out or was asleep in bed, to ring someone at home and yell at him, or persistently to visit a person seeking an interview about some alleged wrongdoing? And how would the action interact with the centuries-old action for trespass just discussed? Is there not a risk that including physical encroachments within the intrusion tort would undermine the carefully developed requirements of that action? It is suggested that the

60 See Mark Simpson, Michael Jones and Anthony Dugdale Clerk and Lindsell on Torts (21st ed, Sweet \& Maxwell, London, 2014) at [19-70]. On the privacy point see Burrows and Todd, above $\mathrm{n} 26$, at [9.2.07(4)]; and W Rogers Winfield and Jolowicz on Tort (16th ed, Sweet \& Maxwell, London, 2002) at [12.75] (the matter is not addressed in subsequent editions). The victim of trespass is also entitled to expel the trespasser where necessary: see Hall v Davis (1825) 2 Carrington \& Payne 33, 172 ER 16 (Assizes); and Halsbury's Laws of England (5th ed, Lexis Nexis, London, 2010) vol 97 Tort at [586]. The victim can claim exemplary damages if, inter alia, "the wrongdoer's conduct has been calculated to make a profit exceeding the compensation payable to the claimant": Clerk and Lindsell on Torts, at [19-70].

61 Ride-alongs (when reporters or members of the public accompany emergency or medical personnel as they attend call-outs) have been the subject of successful intrusion claims in the United States: see for example Miller v National Broadcasting Co, above n 15; Shulman v Group W Productions Ltd 955 P 2d 469 (Cal 1998); and De May v Roberts 9 NW 146 (Mich 1881). They would also be actionable under the New Zealand intrusion tort (even on the narrow formulation of the action being proposed here) as soon as the defendant watched, listened to or recorded anything that could be regarded as private. For persuasive discussion of the need to protect vulnerable people from ride-alongs see Moore, above n 40, at 394-396.

62 See Harassment Act 1997; and Summary Offences Act 1981, s 29. Trespass was unavailable to the plaintiff in Kaye v Robertson [1991] FSR 62 (CA) who was interviewed and photographed in by tabloid journalists while lying in his hospital bed recovering from brain surgery. It would also be unavailable if the intrusion took place in a hotel room or the house one shares with one's parents: Khorasandjian v Bush [1993] QB 727 (CA). 
benefits of including physical intrusions into "private or personal places" within the intrusion tort are not significant enough to justify the uncertainty that these unanswered questions create.

\section{Computer hacking and other forms of information acquisition}

So far then, this article has argued that the intrusion tort should focus on wrongful watching, listening and recording of a person. Incursions into private places and the dissemination of recordings should be dealt with by the Hosking tort, trespass and other actions. But where does that leave privacy interferences which fall within the first of the six subcategories identified above, ie the acquisition of private information without subsequent publication? Should these kinds of privacy breaches - computer hacking, analysis of call data, intercepting e-mails or text messages - be part of the intrusion action?

Hacking which involves the interception of a telephone or video call clearly falls within the intrusion tort as it is being defined in this article. So too would hacking which uncovers recordings or images (particularly intimate "selfies") stored on the plaintiff's digital device. In both situations, the hacking enables the intruder to see and/or hear the claimant engaged in private activities; to look at the plaintiff against his or her wishes. But what say the hacking just reveals non-sensory information, for example, what the claimant was writing in e-mails, searching for on Google, spending his or her money on, or writing about in personal documents? If the material is not disseminated further, such conduct will not be caught by the Hosking tort.

The Court of Appeal in Graham doubted whether such interferences should be actionable under the intrusion tort. Fogarty $\mathbf{J}$ said that because "[s]eclusion as a concept ... connotes an invasion of physical privacy, impinging on one's personal autonomy", whether it extends to interferences with stored information or digital data is "controversial". ${ }^{63}$ But in light of the range and intimacy of material stored on modern personal devices, there is a strong argument that such an intrusion should be civilly actionable in some way. Perhaps courts should be willing to see observation of a person's digital activity - by reviewing or monitoring his or her bank transactions, telephone calls or e-mail traffic, for example - as a form of watching or surveillance akin to listening in on telephone messages or trailing someone as they go about their everyday business. ${ }^{64}$ If so, such activity could potentially fall within an intrusion tort which has as its gravamen protection from watching and listening.

63 Graham $v$ R, above $\mathrm{n} 36$, at [26(c)].

64 The leading Ontarian intrusion case involves a bank clerk who accessed her partner's former wife's bank details at least 174 times over four years: Jones $v$ Tsige 2012 ONCA 32, 108 O.R. (3d) 241. The Court of Appeal held that the facts "cry out for a remedy" and awarded the plaintiff CA $\$ 10,000$ in damages: at [69] and [90]. In New Zealand, it is an offence under the Crimes Act 1961, ss 249 and 252 to access a computer system for a dishonest purpose or without authorisation respectively. 
If this reasoning were considered unattractive, however, New Zealand courts could alternatively address the acquisition of private information via the action for breach of confidence. In Tchenguiz $v$ Imerman, the Court of Appeal of England and Wales held that simply obtaining private or confidential information can create liability in that action. ${ }^{65}$ It followed that the defendants, who accessed, copied and passed on to their sister's solicitor, documents which her estranged husband kept on a computer server in their shared office, were liable for a breach of confidence. Speaking for the Court, Lord Neuberger MR said: ${ }^{66}$

... intentionally obtaining such information secretly and knowing that the claimant reasonably expects it to be private, is itself a breach of confidence ... looking at documents which one knows to be confidential is itself capable of constituting an actionable wrong (albeit perhaps only in equity) ... In our view, it would be a breach of confidence for a defendant, without the authority of the claimant, to examine, or to make, retain, or supply copies to a third party of, a document whose contents are, and were (or ought to have been) appreciated by the defendant to be, confidential to the claimant.

The claimant was therefore able to restrain the defendants from looking at the documents again, even though there was no evidence that they intended to reveal the contents to any third party. ${ }^{67}$

If New Zealand courts were to follow this approach - and it might be open for them to do so then obtaining information or images about a person by hacking into a computer would be actionable at common law. ${ }^{68}$ Detailed discussion of the desirable scope of the New Zealand breach of confidence action is beyond the scope of this article, but since the Hosking court eschewed the

65 Tchenguiz v Imerman [2010] EWCA Civ 908, [2011] Fam 116.

66 At [68]-[69]. This was a significant expansion of the concept of "misuse" which had hitherto involved something more than access to confidential information, such as disclosure to a third party or unauthorised exploitation of trade secrets: see Tanya Aplin, Lionel Bently, Phillip Johnson and Simon Malynciz Gurry on Breach of Confidence: The Protection of Confidential Information (2nd ed, Oxford University Press, Oxford, 2012) at [15.02] and [15.18]-[15.23]).

67 Tchenguiz, $v$ Imerman, above n 65, at [72].

68 Since Tchenguiz $v$ Imerman is a traditional breach of confidence decision (in the sense that the Court was purporting to apply traditional confidence principles rather than the privacy-tort version of the confidence action developed since Campbell v MGN Ltd, above n 15) it would seem to be open to New Zealand courts to follow it. However, the Court was proceeding on the basis that is desirable for privacy and traditional breach of confidence develop consistently (at [66]-[67]) and relied on European Court of Human Rights "private life" cases in reasoning (at [68]). But the extent to which the New Zealand law of confidence extends beyond situations where there is an established relationship between the parties is contested. Compare the narrow views expressed in Hosking $v$ Runting, above $\mathrm{n} 1$, at [46], [201] and [245] with Hammond J's more expansive position in $R v X$ [2009] NZCA 531, [2010] 2 NZLR 181 at [47], all usefully discussed in Cheer Burrows and Cheer: Media Law in New Zealand, above n 26, at 296-298. In Rogers $v$ Television New Zealand Ltd, above n 3, at [24] Elias CJ acknowledged the importance of the relationship with breach of confidence to the development of the privacy tort at issue in that case, namely giving wrongful publicity to private information. 
English approach of extending breach of privacy to protect privacy rights, we should be cautious about developing parallel actions in confidence to make up for perceived shortcomings in the privacy torts. ${ }^{69}$ Of the two possibilities just canvassed, including hacking within the intrusion tort concept of watching or surveillance would therefore seem to be preferable.

\section{HOW THE INTRUSION TORT SHOULD DEVELOP}

\section{A The Reformulated Action}

It is suggested then that the New Zealand intrusion tort should be refined so that rather than requiring an "intrusion into seclusion (namely intimate personal activity, space or affairs)", it requires as its key component an intrusion into physical privacy by watching, listening to or recording a person (with watching potentially including observation of intimate digital activity). When considering whether the expectation of privacy was reasonable, courts should consider a number of specific factors. ${ }^{70}$ The first is where the plaintiff was when the observation or recording took place: was it a place like a home or a toilet cubicle where people would normally expect privacy or was it a place which would generally be regarded as public ? ${ }^{71}$ Secondly, courts should consider the nature of the activity in which the plaintiff was engaged with sexual activity, toileting, intimate conversations and the experience of trauma, grief or shock carrying particularly strong protections. Thirdly, the expectation of privacy should be stronger if a person's intimate body parts were exposed. Finally, courts should consider the nature of the intrusion including whether a recording was made and whether the observation was part of systematic surveillance of the subject. If either of these features was present, the plaintiff's reasonable expectation of privacy would be stronger. ${ }^{72}$ If, in light of these considerations, prevailing social mores say the activity is private then the observation and/or recording would be actionable.

A robust defence to the intrusion action is needed, however, to prevent the action from interfering with legitimate attempts to expose harmful or wrongful behaviour. But, rather than ask whether there was a public interest in any information obtained (as suggested in Holland), this defence should focus on reasons why it might be justifiable to breach a person's privacy by looking

69 Ursula Cheer has also made this point in connection with the issue of identifiability: see Ursula Cheer "Privacy: consolidation and further questions" [2007] NZLJ 117 at 119.

70 The first, second and fourth of which were also identified in the context of the English misuse of private information tort in Murray v Express Newspapers Plc, above n 40, at [36].

71 The fact that an intrusion took place in public would not be determinative, however. The action could potentially be relied on by people are filmed in public whilst their intimate body parts are involuntarily exposed or bugged in public during an otherwise inaudible conversation: see Shulman v Group W Productions Ltd, above n 61. See also NA Moreham, "Privacy in Public Places" (2006) 65 CLJ 606; and McKenzie, above n 23, at 89-93.

72 If the plaintiff was subjected to systematic surveillance then this should strengthen his or her expectations of privacy even if the defendant never observed activities that were particularly private in themselves. 
at, listening to or recording him or her without leave. It could ask, for example, whether the defendant reasonably believed, at the time that it was undertaken, that the unwanted spying, listening or recording was necessary to expose harmful or wrongful behaviour. ${ }^{73}$ If the intrusion took place in public, there could also be an additional defence if the defendant's action was necessary to provide appropriate media coverage of an event of national or international significance. ${ }^{74}$ As with the publicity tort, the more intrusive the defendant's conduct, the more compelling the justification for it would have to be. Thus, whilst it might be almost impossible to justify filming a person using a shower or toilet, it might be relatively easy to defend the surreptitious recording of an otherwise consensual encounter such as a telephone call. Further, since the physical privacy action is predicated on the need to protect the human values of autonomy and dignity, it should only avail natural persons. Corporations, companies and other artificial persons should not be able to rely on it.

The combination of a clear conceptual understanding of physical privacy, express criteria for determining whether there was a reasonable expectation of privacy, and robust defences would obviate the need for the "highly offensive to a reasonable person" check on the intrusion action. It is almost impossible to imagine a situation in which it would not be highly offensive for a defendant to watch, listen to or record a person in circumstances where he or she has a reasonable expectation of privacy on the criteria set out above. And if the defendant's motives were noble, the defences will avail it. In these circumstances, the highly offensive test merely adds an unpredictable extra element to the action and, by raising the bar to recovery too high, risks excluding meritorious claims. ${ }^{75}$

\section{B How Should Intrusion Fit with the Publicity Tort?}

An intrusion tort which focuses on observation and recording would interact with the Hosking publicity tort without difficulty. Cases which involve the publication of private information will fall into the publicity tort whilst those involving watching, listening and/or recording without publication will fall into the intrusion tort. So, for example, to post someone's medical secrets, sexual fantasies or diary ramblings on the internet would breach the publicity tort but, since there was no unwarranted access to the plaintiff's physical person, not the intrusion tort. Conversely,

73 The word "necessary" is intended to imply that the defendant could not have exposed the truth using less intrusive means. For further discussion of these issues see McKenzie, above n 23, at 97-100; and Lyrissa Barnett Lidsky "Prying, Spying, and Lying: Intrusive Newsgathering and What the Law Should Do About It" (1998) 73 Tul L Rev 173, discussing defences in the American context.

74 This defence would most obviously apply if the appearance of the plaintiff was incidental to the filming of an event of significant national or international importance such as the aftermath of an earthquake or workplace disaster. The defence should be less likely to apply if the event was a tragic but common one (such as a car accident), if the subject or someone with him or her was asking for the filming to stop, if the filming was otherwise clearly exacerbating the subject's distress, or if the filming did not relate to the newsworthy event itself but to the grief of victims or family members suffered afterwards.

75 See above n 40. 
spying on people in their bedrooms, bugging their living rooms or filming them using a toilet would not satisfy the requirements of the publicity tort (because the defendant has not published the recordings) but would be a significant physical intrusion. Where both torts are at stake, courts would consider the two claims in tandem. Thus, a person who hacks your telephone calls and broadcasts their content will be liable for both the hacking itself (under the intrusion tort) and for publicising private information (under the publicity tort). Compensation for the intrusion would focus on harm caused by the listening itself: feelings of violation, anxiety, mistrust and, perhaps, the exacerbation of existing mental health problems. Compensation for the publicity tort would focus on the humiliation, embarrassment, and possible pecuniary damage caused by the disclosure. Problems of double-counting therefore need not arise. ${ }^{76}$

The defences to the two torts would also reflect the particular privacy interests at the heart of each action. As discussed, whilst the publicity tort defence should focus on whether there was a legitimate public concern in the information published, the intrusion tort should ask whether there was justification for the act of looking, listening or recording itself. This means that a right to disseminate will not always follow a right to watch, listen or record and vice versa. Thus, whilst a concerned son might have a defence if he installed a video camera to investigate suspicions that his mother's carers were neglecting her (having formed a reasonable belief that the recording was necessary to expose wrongdoing) there might be insufficient public interest in the footage to justify disseminating it. $^{77}$

\section{CONCLUSION}

The tort of intrusion has an important role to play in the protection of privacy in New Zealand common law. It recognises - quite rightly - that privacy is not just about the protection of private information but also about bodily and spatial integrity; the right to be free from unwarranted spying, eavesdropping, bugging and filming when engaged in something private. Protecting these privacy interests requires constant negotiation between the need for certainty and flexibility. This article argues that that balance is best struck by proscribing unwarranted watching, listening or recording in circumstances where the subject has a reasonable expectation of privacy as defined by a number of clearly delineated criteria. Clear defences should also apply. An action of this nature - clearly conceptualised, precisely formulated and subject to appropriate defences - will provide important

76 For an example of a case where plaintiffs were compensated for physical and informational privacy interferences separately see the English telephone hacking case of Gulati v MGN Ltd, above n 48.

77 The converse might also be true. For example in Shulman v Group W Productions Ltd, above n 61, the Supreme Court of California held that although it was an actionable intrusion to record conversations which took place between the plaintiff and paramedics who assisted her after a serious road accident, broadcast of the footage was justified because it was "newsworthy". Such situations are likely to be rare in New Zealand, however, since freedom of expression does not act as a trump card in the way it does in the United States on account of courts' interpretation of the First Amendment to the United States Constitution. 
protection for individuals' physical privacy interests. It will also, it is hoped, help show how privacy can be translated into a workable legal concept both within the common law and beyond. 